\section{The CHESSBOARD Classi- fication Scheme of Mineral Deposits: Mineralogy and Geology from Aluminium to Zirconium}

\author{
By Harald G. Dill, \\ Earth Science Reviews (Elsevier), \\ Volume 100, June 2010, 420p. \\ ISSN: 0012-8252. \\ Price varies (read below).
}

Although by the publisher's definition this is a 'single article', it nevertheless occupies the whole of Volume 100 of the Earth Science Reviews. At 420 pages, A4 format, of a very dense, two-column print, this is actually a major book in everything but name: an approximate equivalent of a $700-800$ page $23 \times 16 \mathrm{~cm}$ volume as in the Elsevier's Developments in Economic Geology series. So why has this work not been published as a book? Well, there are certain reasons ... ; more about them below.

Dill's 'chessboard' appears in colour on the journal's cover, where fifteen chess pieces are substituted by thumbnail images of minerals and mine workings, with the sixteenth piece being represented by an oversize picture of an open pit mine. The 'real' chess King overlooks the lot. Once inside the text the 'chessboard' metaphor is followed, in brackets, by the term spreadsheet, and in fact the reader will instantly recognize the uncanny resemblance to the Microsoft Excel workbook. After a brief introduction, with a list of minerals complete with formulae and line numbers, comes the 'heart' of the book and the basis of Dill's classification (alias organization) of knowledge about mineral commodities and their occurrences: a set of 21 spreadsheet-style index pages. These pages have colour-coded cells for each of which the colour indicates one of the eight genetic groupings (e.g. mineralization caused by metamorphogenetic processes; but the other groups are rather unconventional). In the spreadsheet the horizontal rows at the top provide column headings, from left to right: e.g. Type of commodity, further subdivided into (i) Gemstones and ornamental stones; (ii) Industrial minerals and rocks; (iii) Ore minerals and metallic resources; (iv) Element-Mineral-Rock. The Formative or deposit-hosting environments/associations

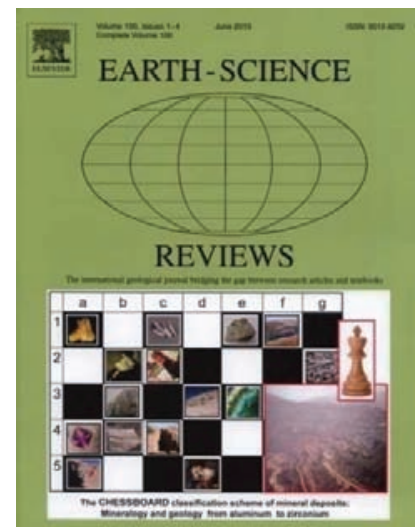

that follow to the right of the spreadsheet are subdivided into fourteen lettered columns (as in Excel). Columns A-E include igneous rocks (ultrabasic, basic, intermediate, felsic that include pegmatite and aplite, alkaline rocks with carbonatites). Columns F and G are structures (pipes/breccias, faults/veins). Columns $\mathrm{H}-\mathrm{M}$ are sedimentary rocks (duricrusts and regoliths, coarse clastics, fine clastics, limestones, evaporites, special sedimentary rocks) whereas Column $\mathrm{N}$ includes special facies (carbon-bearing rocks). The perennial problem of ore deposits classification, that of alternating categories based on host rocks with those based on orehosting structures and/or (presumed) origin, again surfaces here. 'Breccia pipes' and 'Vein zones' (columns F and G) include deposits that can also be igneous-rocks hosted or related (columns A-E), or located in sediments (columns $\mathrm{H}-\mathrm{L}$ ). There is not much one can do except to include the same deposit in more than one column (which Dill has sometimes done) and call the process 'organization' rather than 'classification' as classification theory requires classes to be mutually exclusive.

The numbered horizontal spreadsheet rows, organized in 63 composite sets of rows under a commodity heading (e.g. Cr, PGE, $\mathrm{Ag}, \mathrm{Ca}, \mathrm{Si}$, feldspar, zeolites, halloysite) comprise mineralization types of a single commodity. As one moves from left to right, within the 'rocks' and 'structures', columns A to $\mathrm{N}$, one encounters successive ore variants of the given commodity as influenced by their setting or style. So, for example, Row $\mathrm{Cu}: 9 \mathrm{~A}$ has 10 occupied cells such as $\mathrm{Cu}-\mathrm{Au}-\mathrm{Ag}-$ Te epithermal (Fiji) or $\mathrm{Cu}-\mathrm{Ni}-\mathrm{Fe}-\mathrm{Co}-\mathrm{Mn}$ nodules, whereas Row Cr:1e has just one occupied cell. This arrangement makes it possible to rapidly determine which commodities and their ore styles are associated with, for example, ultrabasics or limestones. The cells for which there are no recognized deposit examples are left blank.

Dill's worthwhile effort to devise a rational organization of ALL mineral commodities, which unables the reader to instantly locate descriptive information about a given group and ore type, has produced a scheme that resembles the dataset of numbered U.S. Geological Survey mineral deposit types (Cox and Singer, 1986, USGS Bulletin 1693, and subsequent variants) that Dill has substantially expanded and 'globalized', combined with Mendeleev's Periodic Table. As in the latter, the 'Chessboard' sheet has predictive value: could there be a gold accumulation in limestones or evaporites presently marked by blank cells? As in the USGS ore-types the progression of numbered commodities is one of many possible-e.g. an alphabetic list (such as might appeal to the non-geologist reader)Dill has employed a frequently-used genetically-flavoured progression, moving from metals predominantly associated with magmatic and basic-ultrabasic systems $(\mathrm{Cr}$, $\mathrm{Ni}, \mathrm{Co}, \mathrm{PGE}$ ) close to the mantle parentage, through igneous-hydrothermal metals $(\mathrm{Cu}$, $\mathrm{Sn}, \mathrm{W}, \mathrm{Be}$ ) albeit with prominent sedimentbased equivalents, into sediments ( $\mathrm{Na}, \mathrm{P}, \mathrm{Si})$ and then 'rocks'-dominated commodities such as asbestos, dimension stone, corundum. Dill has assembled a comprehensive selection of commodity examples (some mere mineralogical curiosities), many virtually unheard-of (e.g. tsavorite, thulite, orthoclase marble). The 'mainstream' ore types are all there, though their naming has a strong subjective component influenced by disputed origin, disagreement as to their key classifiers, and a difficulty to accommodate cases with two or more classifiers of more or less equal importance. So the Column F, 'pipes', includes examples like Olympic Dam where pipe structure is hard to see, while omitting the obvious pipes so named in the literature, such as Vlakfontein [Ni] or Onverwacht [PGE]. The latter, instead, appear in the general Column A assigned to ultramafics. The placement of Olympic Dam illustrates the controversy of rational ore classification: the $\mathrm{Fe}, \mathrm{Cu}, \mathrm{U}, \mathrm{Au}, \mathrm{REE}$ minerals there are disseminated in an irregularly-shaped zoned breccia body and are of hydrothermal origin. Although hosted mostly by anorogenic granite the mineralization process, its agents and timing remain controversial. Placed into the largely metal/alteration defined class of Iron Oxide-Copper-Gold (IOCG; Hitzman et al., 1992, Precambrian Research 58, 241287) the 'Dam' resists attempts of allocating 
it a rational (or 'natural') place in the assembly of global ores. The reader will have to get used to Dill's 'mixtum compositum' and utilize his or her chessboard as a 'search engine' for information in the main body of the book that follows. There, factual descriptions of the commodity groups are assembled in numerical order. Sequence stratigraphy, an important exploration tool in hydrocarbons search, has hitherto been rarely used for metallogenic analysis in terrains prospective for sedimentogenic and supracrustals-related metal accumulations. Dill, however, has incorporated this concept into his compilation, based mainly on original studies in the Variscan and Alpine orogens of central Europe.

A typical numbered descriptive commodity section ranges from less than a quarter of a column (60 B-D: Prehnite) to 21 pages (11: Copper). Section 24: Uranium, thorium and radium, has 16 pages and numbered sub-sections devoted to $\mathrm{U}$ and $\mathrm{Th}$ chemistry and mineralogy; to uranium deposits subdivided into magmatic, structurebound, sedimentary sub-sections. The Th subsection is further subdivided into magmatic, structure-bound, and sedimentary ores. The concluding paragraph reviews $\mathrm{U}$ and $\mathrm{Th}$ supply and uses. The descriptions are concise but rich in 'facts' many of which are close to 'juvenile': if not newly contributed by the author, then at least culled from obscure, small circulation, multilingual or other hard to get literatures that are rarely harvested by mainstream Anglophone writers. There are links to on-line databases at the U.S. Geological Survey and elsewhere that will make possible frequent updates of the numerical data (which change over time) whereas the geological descriptions that change but slowly (and are not provided by the same databases) remain. This extends the 'shelf life' of this publication. The descriptive part has many figures and mostly original field and sample photographs. In the hard copy, the photos are in black and white and, as is the universal problem, sometimes suffer from poor resolution. The electronic book version, however, has all photos in vivid colour. The book is well written, taking into account the author's self-translation with a minimum of editorial assistance. There are a few minor errors, mostly in the spelling of some locality names. They do not detract from the value of this work as a rich, truly global reference, but in the age of computer keyword searching the reader is advised to check locality spelling if told 'not found' by the computer.

Harald Dill wears two hats. He is a scientist with the German Geological Survey in Hannover (BGR) and although an internationally versed mineral deposit specialist his present projects have little to do with ores. So he pursues his mineralsloving passion 'after hours', wearing his second hat, as an Associate Professor at Mainz University (visit www.hgeodill.ge). This case is quite common among the handful of surviving 'ore encyclopedists'.

Now, who should buy this book? Anyone interested in ALL mineral commodities, ANYWHERE. The work of a single author ensures that there are no gaps between specialities as is the case with many modern collective works (e.g. Economic Geology, $100^{\text {th }}$ Anniversary Volume, 2005). The primary focus of this book is mineral commodities, so in addition to mineral practitioners in regions where mining and exploration are alive and vigorous, like Nevada, Canada, Australia and Latin America, this book is also essential reading in industrialized countries that depend on mineral imports from abroad. Germany is a glaring example: originally a mineral-rich country whose resources provided considerable wealth in the pre-industrial era, co-sponsored the Industrial Revolution, and had 600 mines operating during World War 2 , it now has not a single metal mine in operation and only a handful of non-metallic producers. All metals are thus imported to Germany. The anticipated future rawmaterials supply shortages (cf. Laznicka, Giant Metallic Deposits: Future Supplies of Industrial Metals, $2^{\text {nd }}$ edn, Springer, 2010) indicate potential future market instability and increasing competition for commodities among importers. It is thus advisable that import-dependent industries and their governments pay attention to, and maintain awareness of, the international sources of supply (Japan, South Korea and China do so). Dill's book will provide much of the information needed to do this under single cover.

As this is a journal volume rather than a stand-alone book, copies have to be ordered through Elsevier's regional Journal Customer Service centres in the UK, USA, Japan or Singapore, listed at the www.elsevier.com website. The prices of journal orders from the large for-profit publishers nowadays resemble the 'pay what you can' practice of buying electronic airline tickets. The Elsevier website lists the annual 'institutional print price' for Earth-Science Reviews (which includes more than one volume) as US $\$ 2,068$ ! If you qualify for 'associated personal print price' it comes down to US\$ 174 and possibly less, though Elsevier quoted me a single issue price of US\$ 402. However, the online edition of the Dill's volume can be accessed by visiting www. sciencedirect.com and, voilà!, you should be able to access this 'article' for a mere US\$ 37.95 .

\section{Peter Laznicka}

Metallogenica Consulting,

Adelaide West Lakes,

SA 5021, Australia

E-mail:plaznicka@dodo.com.au 